\title{
Hydrothermal fluorapatite in magnesian skarns from Valea Rea (Budureasa, Bihor Mountains, Romania)
}

STEFAN MARINCEA, ADRIAN IULIAN IULIAN PANTIA, DELIA-GEORGETA DUMITRAS, CRISTINA SAVA GHINET AND ANDRA ELENA FILIUTA

Geological Institute of Romania

Presenting Author: smarincea@yahoo.com

The occurrence of magnesian skarn from Valea Rea occurs in the close proximity of the southern contact of the Budureasa laccolith $(-74 \pm 3$ to $-73 \pm 3 \mathrm{Ma}$ according to $\mathrm{K}$-Ar ages $)$ with Anisian dolostones pertaining to the Ferice Unit. Well-shaped crystals of fluorapatite were identified in forsterite- and phlogopite-bearing skarns located on the waste dump of an exploration shaft, dug in the late 1980's near the southern contact of the intrusive body. The coordinates of the shaft entry, known as "Shaft 2", are N 46 39'49" - E 22 36'44". Fluorapatite and rare fluorite $\left(\mathrm{Ca}_{0.9984} \mathrm{Mn}_{0.001} \mathrm{Ni}_{0.001} \mathrm{~F}_{2}\right)$ were identified as swarms of crystals or agglomerations in calcite veins that crosscut the skarn. Individual crystals have columnar habit, are of up to $1 \mathrm{~mm}$ in length and $0.3 \mathrm{~mm}$ in width, having a simple combination of forms consisting of prisms $\{100\}$ and low pyramids $\{101\}$. The average composition resulting from the EMPA analyses on ten different samples is (in wt.\%): $\mathrm{P}_{2} \mathrm{O}_{5}=42.05, \mathrm{SiO}_{2}=0.09, \mathrm{Ce}_{2} \mathrm{O}_{3}$ $=0.03, \mathrm{La}_{2} \mathrm{O}_{3}=0.03, \mathrm{CaO}=55.40, \mathrm{MnO}=0.02, \mathrm{FeO}=0.04$, $\mathrm{MgO}=0.03, \mathrm{~F}=4.52, \mathrm{Cl}=0.01, \mathrm{O} \equiv(\mathrm{F}, \mathrm{Cl})=-1.91$, Total $=$ 100.31. Normalized to $3(\mathrm{P}+\mathrm{Si})$ and $13(\mathrm{O}+\mathrm{F}+\mathrm{Cl}) p f u$, this yields to the formula:

$$
\begin{aligned}
& \left(\mathrm{Ca}_{4.989} \mathrm{Mn}_{0.001} \mathrm{Fe}^{2+}{ }_{0.003} \mathrm{Mg}_{0.003} \mathrm{Ce}_{0.001} \mathrm{La}_{0.001}\right)\left(\mathrm{P}_{2.992} \mathrm{Si}_{0.008}\right) \\
& \left(\mathrm{O}_{11.894} \mathrm{~F}_{1.202} \mathrm{Cl}_{0.001}\right) .
\end{aligned}
$$

The cell parameters of two representative samples are: $a=$ 9.385(7) $\AA$ and $c=6.891(9) \AA$, and $a=9.382(4) \AA$ and $c=$ $6.889(5) \AA$, respectively. The indices of refraction, taken as mean of measurements on ten different grains, are: $w=1.634(2)$ and $e$ $=1.631(1)$. The calculated densities of the same two representative samples are $D_{\mathrm{x}}{ }^{\prime}=3.196 \mathrm{~g} / \mathrm{cm}^{3}$ and $D_{\mathrm{x}}{ }^{\prime \prime}=3.202$ $\mathrm{g} / \mathrm{cm}^{3}$, respectively, resulting in a mean density $D_{\mathrm{x}}=3.199$ $\mathrm{g} / \mathrm{cm}^{3}$, which compares well with the measured density, $D_{\mathrm{m}}=$ $3.201(3) \mathrm{g} / \mathrm{cm}^{3}$. Calculation of the Gladstone-Dale compatibility indices gave in all cases values indicative of superior agreement between physical and chemical data. In the infrared spectra, the multiplicity of the bands assumed to phosphate modes $\left(2 v_{1}+\right.$ $3 v_{2}+5 v_{3}+5 v_{4}$ ) agrees with the reduction of the symmetry of $\mathrm{PO}_{4}{ }^{3-}$ ion from $T_{d}$ to $C s$. 